\title{
The journey of a drop in a static mixer
}

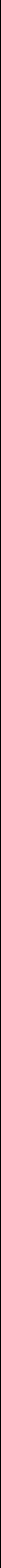

